\title{
Valuing Ecological Restoration and Recreational Benefits in a Mountain Protected Area: The Case of Los Nevados National Park, Colombia
}

\author{
Sergio Alvarez (Corresponding author) \\ Department of Food and Resource Economics, University of Florida \\ G-105 McCarty Hall B, PO Box 110240, Gainesville, FL, USA \\ Tel: 1-352-392-1845 E-mail: sergioal@ufl.edu \\ Sherry L. Larkin \\ Department of Food and Resource Economics \\ University of Florida, USA
}

Funding for this project was provided by the Tinker Foundation and the Tropical Conservation and Development Program at the University of Florida. The Colombian National Parks Service and Concesion Nevados provided valuable assistance during data collection. Publication of this article was funded in part by the University of Florida Open-Access Publishing Fund.

\begin{abstract}
This study uses travel cost and contingent valuation methods to derive estimates of economic value for recreational use of Los Nevados National Park in the Andean region of Colombia. Park visitors were surveyed regarding their travel costs and willingness-to-pay (WTP) for ecological restoration of areas affected by wildfires in 2006. The travel cost data was analyzed using a zonal travel cost model. The contingent valuation experiment used a dichotomous choice format followed by an open-ended question asking for their maximum WTP for restoration. Consumer surplus for recreational use of the park was found to be large relative to the budget of the Colombian Parks Service, which justifies continued funding. Respondents' WTP for ecological restoration was modest and possibly influenced by bequest values, but unaffected by potential information bias.
\end{abstract}

Keywords: Travel cost, Contingent valuation, Non-market value, Protected area, Ecological restoration

\section{Introduction}

Protected Areas (PAs) are widely regarded as the cornerstones of biodiversity conservation strategies worldwide, providing the main foundation for in situ conservation of flora and fauna, and being an important element of any sustainable development plan (Convention on Biological Diversity, 2004). Furthermore, national parks and other PAs contribute to human well-being in a variety of ways (McNeely, 1995). However, economically efficient resource management requires knowledge of the flow of park benefits and costs, including non-market benefits (Mathieu et al., 2003). Public benefits derived from a national park in the form of environmental amenities and ecosystem services implies that the park contributes to public welfare, and loss of the park or decline in park quality could result in a loss in welfare (Shah, 1995). Information on the welfare contribution or economic value of protected areas in developing countries, however, is scarce.

Non-market valuation techniques, such as the Travel Cost Method (TCM) and the Contingent Valuation Method $(\mathrm{CVM})$ can be used to measure the economic value of recreation in PAs. The TCM has been used to estimate recreational benefits associated with golfing (Loomis et al., 2009) and visits to a natural attraction in a World Heritage Site (Fleming and Cook, 2007). Willis and Garrod (1991) compared zonal and individual TCM value estimates for recreation in forests. On the other hand, CVM applications in the literature range from examining WTP for public projects in urban areas (Weldesilassie et al., 2009) to the protection of vast and isolated areas of tropical forest (Horton et al., 2003). Recently, the use of CVM for improving PA management or developing sustainable ecotourism in national parks has received considerable attention (e.g., Shamsudin et al., 2009; Yacob et al., 2009; Samdin et al., 2010). When it comes to the question of restoration of ecological goods or services, the majority of previous studies involve valuing the restoration of river flows and riparian ecosystems (e.g., Ojeda et al., 2008; Loomis et al., 2000). The restoration of native land ecosystems has also been investigated in the United Kingdom (MacMillan and Duff, 1998). Similar studies have also estimated values for improving the conditions or infrastructure of a park (e.g., Jabarin and Damhoureyeh, 2006; Mathieu et al., 2003). A few studies have combined the use of TCM and CVM to measure the economic benefits of protected areas in the developing world (e.g., Navrud and Mungatana, 1994; Maharana et al., 2000).

The purpose of this study was to estimate the recreational use value accrued to visitors to Los Nevados National Park in Colombia, and the visitors' WTP for restoration of areas affected by wildfires that occurred in 2006 . In addition, valuations were tested for sensitivity to information about the ecosystem services provided by the park, 
as well as respondent characteristics. In the following section, section 2, the study location and data collection process are described. In section 3 the travel cost and contingent valuation methods are introduced, with special emphasis on the theory and empirical application of these methods. Section 4 presents the estimation results and interprets the important parameter estimates. In section 5 the results are discussed and implications for management or protected areas are emphasized. Finally, section 6 offers some brief conclusions.

\section{Study Area and Data Collection}

Los Nevados National Park (LNNP) is located in central Colombia and is comprised mostly of Andean cloud forest and páramo - a high altitude grassland unique to northern South America. Initially established in 1973 to encompass 38,000 hectares of glaciated peaks and páramo, the park has since expanded to its current 58,300 hectares. Given its central location in the densely populated Andean region of Colombia, the LNNP has attracted an increasing number of visitors, reaching a high of 80,000 in 2004. Most visitors are Colombian nationals drawn to the park by the presence of the glaciated peaks. The park serves an important hydrological function as it contains several rivers that provide drinking water for at least two million people in the surrounding area. The park also provides critical habitat for several species including the Andean spectacled bear (Tremarctos ornatus) and the Andean condor (Vultur gryphus), but other tropo-montane flora and fauna are present. Unfortunately, a series of wildfires swept through the LNNP and burned close to 2,500 hectares of páramo in July 2006.

Data used for the analysis were obtained from personal interviews conducted at the LNNP during July 2007.A total of 64 Colombian visitors were interviewed. The travel cost section of the interview asked respondents to list their expenses for transportation, lodging, equipment rental, and guidance services. The contingent valuation section of the interview began by asking respondents how familiar, if at all, they were with the wildfires that occurred in 2006. Then, they were informed about the magnitude and location of the wildfires and were confronted by a scenario in which the park authorities are considering an increase in the park admission fee to cover restoration expenses. A card with the proposed fee increase (one of four values) was then shown to the respondent, followed by the question:

Please consider how much you spend on recreation each year, including the cost of this trip. Would you have been willing to pay this extra amount per person during this visit?

The four price levels were $25 \%, 50 \%, 75 \%$, and $100 \%$ increases of the existing entrance fee of 8,000 Colombian Pesos (COP, approximately \$4USD). Regardless of their response, respondents were then asked to identify their maximum willingness to pay an increased fee as an open-ended question.

Secondary visitation data were obtained from the National Parks Service of Colombia and the private Concessionaire (Concesión Nevados) that manages tourism within the park. The secondary data is a census of information all park visitors (e.g., home address) for October and November 2006 and January through May of 2007. The data set contained 26,246 observations.

\section{Methods}

Several methods can be used to quantify the value that individuals place on natural systems. The idea of measuring the economic value of recreational use through the expenditures in complementary market goods, which is the basis of the TCM, was first proposed by Harold Hotelling in a letter to the director of the U.S. National Parks Service in 1947 (Arrow and Lehmann, 2005). Hotelling argued for using travel costs as a conservative measure of site value because entrance fees are either not collected or are very low so are not a good measure of value. An alternative approach, the CVM, can be used to measure proposed changes in the environment. This method elicits individual behavior in a hypothetical market such that all responses are 'contingent' on the fictional market. As such, this approach can capture the WTP for a variety of non-market values (Hanemann, 1994). This study employs both the TCM and CVM, as recommended by Cameron (1992). The application of each is described in turn.

\subsection{The Travel Cost Method}

The TCM uses individuals' recreational expenditures as a basis for estimating the value of a non-market good (e.g., public park) as if it had been available in a well-functioning market (Clawson and Knetsch, 1966). Economic theory suggests that the quantity purchased of any good is a function of its price. As such, a recreation demand curve can be developed using observations on visitation (i.e., demand) and expenses incurred during visits (i.e., the price of the experience. Conceptually, visitation is a function of travel costs, such that:

$$
V_{j}=f\left(T C_{j}\right) \text {, }
$$

where $V_{j}$ is the visitation rate of zone $j$ and $T C_{j}$ is the average travel cost from zone $j$ to the recreational site. The zonal TCM divides the visitation observations into zones based on their location relative to the site and uses historical records of visits per capita within each zone as the measure of visitation to the site.

Given that many parks record the number of visitors and their places of origin, the zonal TCM can be easily used to quantify the economic benefits of these areas (Clawson and Knetsch, 1966). Thus, the zonal TCM is a viable alternative to more complex and costly (albeit more precise) techniques, such as the random utility approach 
(Bockstael et al., 1991) or the individual TCM (Willis and Garrod, 1991), all of which require richer datasets. This advantage is especially relevant in developing countries, where the necessity of conducting non-market valuation studies is more likely to be ignored due to the prohibitive costs of more precise studies.

Some problems with the zonal TCM approach have been discussed in the literature. Bowes and Loomis (1980) show that differences in population size between zones results in heteroscedasticity. To solve this problem they propose estimation using Generalized Least Squares (GLS). This ensures the estimators will have equal variances and possibly improves the statistical properties of the estimates. The measurement of the opportunity costs associated with time spent in a recreational area is another difficulty of the zonal approach. Omission of the opportunity costs of travel time will result in downward-biased coefficients of travel cost and biased welfare measures (Loomis et al., 2009). While a zonal average of the opportunity costs of time is conceptually adequate, the practical difficulties of defining such a measure in a country like Colombia preclude its inclusion in this study. Another shortcoming is that the zonal TCM ignores the existence of substitute recreational sites, which may also result in biased welfare estimates. Problems also arise when the recreational site is near a zone with a relatively large visitation rate. These latter concerns are not as applicable to the LNNP since the park is relatively large and isolated.

With the zonal TCM approach, secondary visitation data is used with population data to estimate visitation rates by zone. The political division of Colombia into states was used for the definition of distinct geographic zones. Visitation rates were calculated using the following equation:

$$
V_{j}=\left(\operatorname{USERS}_{j} / P O P_{j}\right)
$$

where $U S E R S_{j}$ is the total number of users from zone $j$ as obtained from the monthly visitor counts $(N=$ 26,246); and $P O P_{j}$ is the population of zone $j$ from the 2005 census. Using reported visitor counts generates a demand for a seven-month period by visitors from 13 states that represent $72 \%$ of the country's population. Thus, the visitation rate underestimates the annual demand of all Colombians.

Given that the zonal TCM uses visitation rates as a proxy for quantity purchased and travel cost as a proxy for price, the following demand function is estimated:

$$
V_{j}=\beta_{0}+\beta_{1} T C_{j}+\varepsilon_{j},
$$

where $\beta_{0}$ and $\beta_{1}$ are the intercept and slope of the demand curve, respectively, and the error term $\varepsilon_{j}$ follows a normal distribution.

The recreational benefits of an environmental amenity can then be estimated by quantifying the area under the demand curve and above the price paid for purchase of the amenity, also known as the consumer surplus (CS). For the zonal TCM, this measure can be expressed as:

$$
C S_{j}=\int_{T C_{i}}^{T C_{j}}\left[\hat{\beta}_{0}+\hat{\beta}_{1} T C_{j}\right] \partial T C_{j} .
$$

$C S_{j}$ is a measure of the surplus value (i.e., wealth) that the individual receives from visiting the LNNP. The sum of individual consumer surpluses, therefore, is a measure of the surplus value that society receives from access to the park.

\subsection{The Contingent Valuation Method}

Since the use of non-market goods and services does not require expenditures, there is no observable behavioral trail left by their use. However, individuals may be willing to spend some of their income or make some tradeoffs to secure access to or use of these goods.

Under this premise, economists have devised questionnaires in which a hypothetical scenario presents the respondent with the choice of paying for the maintenance or improvement of a good or service that is currently 'free'- that is, a non-market good or service. Conversely, respondents could be asked for their willingness to accept (WTA) compensation to forgo a benefit to which they are entitled (Van Kooten and Bulte, 2000). In this study, it was more realistic to ask about a WTP for restoration from damage that has already occurred than a WTA compensation for inability to use a portion of the park.

Several problems with the CVM have been identified throughout the literature and most of them result from the hypothetical nature of the approach (Hanemann, 1994). The idea of placing a monetary value on environmental goods or services is unfamiliar to respondents as they seldom think of these goods or services in monetary terms. Respondents may also perceive the same good or service very differently, and their conceptualization of the good may be divergent from that of the researcher. Respondents to CVM questionnaires may also have trouble separating different attributes of ecosystems, a process known as embedding. When these differences in conceptualization exist, the information given by the researchers may affect responses, resulting in information bias. The choice of payment vehicle may result in protest responses if individuals may be unwilling to pay in the way they are asked to (e.g., taxes), not because they do not value the good or service. Some respondents may also feel good when overstating their WTP, a phenomenon known as the 'warm glow' effect. Respondents may 
also answer positively to questions, thinking that positive answers will result in a particular outcome even though they are not willing to pay the elicited amount (i.e., strategic bias). If respondents are prompted for their WTP through a bidding game, the initial bid will also affect their final response as respondents anchor their WTP to the initial bid amount, a process known as starting-point bias (Whitehead, 2002). While all these problems are sources of concern for researchers, improvements in questionnaire design have partially or completely addressed most of these issues (Hanemann, 1994).

In recent CVM studies, a single bound dichotomous choice (DC) format has been used to address some of these concerns. Respondents are asked whether they would be willing to pay a specified amount for the good or service in question, followed by an open-ended experiment in which they are asked to provide their maximum WTP (Ojeda et al., 2008). In the closed-ended DC portion, different respondents are confronted with different prices. Conceptually, this process should result in a downward sloping demand curve, as more respondents are expected to respond positively to low prices and vice versa for a normal good.

In this study, the single bound DC format with the follow-up maximum WTP is used to reduce the potential for starting-point bias. Each model is described in turn below. Hypothetical bias and payment vehicle bias are not expected since the interviews were conducted in the park entrance. It is possible to test for information bias through survey design, but warm glow bias will only be evident ex post if the positive responses are overwhelming.

\subsubsection{Closed-ended Dichotomous Choice WTP Model}

The decision process of a respondent to the DC experiment can be modeled in a simple utility framework following Hanemann (1984). Let the utility or satisfaction of a visitor to LNNP be given by:

$$
u=u(y, x, q) \text {, }
$$

where utility $(u)$ is a function of income $(y)$, personal characteristics $(x)$ and the quality of the park $(q)$ as perceived by the visitor. Furthermore, let there be two states of the world corresponding to different levels of environmental quality: $q$ as the quality after restoration of the park and $q^{\prime}$ as the quality before restoration or if restoration is not pursued.

If $A$ is the amount the respondent is asked to pay to finance restoration of the park, the respondent will choose to pay (i.e., give a 'yes' response) if:

$$
u(y-A, x, q) \geq u\left(y, x, q^{\prime}\right) .
$$

In essence, the individual is willing to pay the specified amount $(A)$ if more satisfaction is received by paying the amount (income becomes $y$-A) and having the park restored than in the status quo where income is unchanged and the park is not restored. Thus, the researcher observes a binomial random variable that takes a value of 1 if the individual is willing to pay $A$ or 0 if they are not. This variable is assumed to reflect the underlying and unobserved response variable $y_{i}^{*}$ that is described by:

$$
y_{i}^{*}=\beta^{\prime} x_{i}+\varepsilon_{i},
$$

where $x_{i}$ is a vector of respondent characteristics and $\varepsilon_{i}$ is an error term.

While $y_{i}^{*}$ is unobservable, we observe the binomial variable $y_{i}$ that takes a value of 1 if $y_{i}^{*}>0$, or a value of 0 otherwise. The probit model is obtained by modeling the probability that $y_{i}$ takes a value of 1 :

$$
\operatorname{Pr}\left(y_{i}=1\right)=\operatorname{Pr}\left(\varepsilon_{i}>\beta^{\prime} x_{i}\right)=1-F\left(-\beta^{\prime} x_{i}\right),
$$

where $F$ is the standard normal distribution (Maddala and Flores-Lagunes, 2001). A logit procedure could also have been used as in previous studies (e.g., Shamsudin et al., 2009; Yacob et al., 2009), but both procedures are likely to yield similar results.

\subsubsection{Open-Ended Follow-up WTP Model}

Respondents who were willing to pay the predetermined amount in the DC portion of the experiment were expected to have a maximum WTP that was at least as high as the predetermined amount. Respondents who were not willing to pay the predetermined amount could be willing to pay a lower amount than they were initially asked. Some respondents, when asked about their WTP above the entrance fee, said the fee was already too high. These respondents have a negative WTP for restoration given the existing entrance fee. The questionnaire did not accommodate negative WTP values so the minimum value was zero, which means the dependent variable is censored at zero. A censored regression model is known as the Tobit model, which also assumes that there is an underlying response variable $y^{*}$ (i.e. the true WTP), defined by the regression relationship:

$$
\begin{gathered}
y^{*}=X \beta+\varepsilon, \\
y=y^{*} \text { if } y^{*} \geq 0, \\
y=0 \text { if } y^{*}<0,
\end{gathered}
$$

where $X$ is a vector of respondent characteristics and $\varepsilon$ is a normally distributed error term (Moffit, 1999). 


\section{Results}

\subsection{Travel Cost Estimates}

In order to identify the best fitting model, a series of models with different functional forms were estimated; notably with the use of a logarithmic form as in previous studies (i.e., Navrud and Mungatana, 1994). All the models were estimated using a GLS approach as suggested by Bowes and Loomis (1980). The results are summarized in Table 1.

The four models yielded parameter estimates whose signs adhere to economic theory, resulting in downward-sloping demand curves. All the parameter estimates for the travel cost variable are negative and statistically different from zero, indicating that as travel costs increase, fewer visits to LNNP are predicted. Goodness of fit measures range from an R-squared of 0.256 to 0.441 .

The estimates of CS for each model specification and each of the zones included in the analysis are shown in Table 2. The total surplus economic value for trips to LNNP for the 13 states included and the seven-month period of available data ranges between 2.2 billion COP (1.1 million USD) or about 83,754 COP per person, and 9.3 billion COP (4.6 million USD) or about 353,483 COP per person.

\subsection{Contingent Valuation Estimates}

Exploration of the factors and personal characteristics that affect respondent's WTP for restoration of areas burned by wildfires in LNNP requires inclusion of these characteristics in the empirical equations. Summary statistics and descriptions of the included variables are shown in Table 3.

\subsubsection{Dichotomous Choice Results}

The WTP responses were analyzed using two probit models. The models were estimated to account for two possible functional forms assumed by the PRICE variable. Given the small number of observations and the relatively small variation among prices, there was no a priori information regarding the correct functional specification for these models. The results of the analysis are summarized in Table 4.

While not all the variables included in the analysis were statistically significant, there were several variables that were statistically significant in both models. Following economic theory, PRICE was statistically significant at the $5 \%$ level in both models. Both the parameter estimate and the marginal effect have a negative sign. This implies that as the proposed entrance fee shown to respondents increased, they were less likely to agree to pay the extra money for ecological restoration. Marginal changes are shown along with the base values with which they were calculated.

Respondents who expressed that they are regular visitors to other National Parks or other natural areas (RVISIT) exhibited a higher probability of being willing to pay for restoration than those who did not. Regular visits to natural areas may indicate a pro-environment attitude, which can be expressed as WTP for restoration of damaged ecosystems. Regular users of natural amenities also have higher direct-use values that result from more frequent use and enjoyment of these amenities.

Survey respondents traveling in tour buses (TOURBUS), most of whom were traveling in large groups, exhibited a higher probability of responding 'yes' to the DC question. It was hypothesized that respondents travelling in large groups would be less likely to respond 'yes', as they were told that the additional fee would apply to everyone in their group. However, tour travel may also reflect an individual's desire to be part of a group that is interested and concerned with nature, thereby resulting in a higher WTP for restoration. On the other hand, tour bus visitors may perceive entrance fees as sunk costs, and they may see the increased entrance fee in relation to the total cost of the package, which is relatively small.

Respondents were queried on their awareness of three different ecosystem services provided by LNNP: hydrologic regulation, habitat for threatened or endangered species, and carbon sequestration, and were given a ECOAWARE value of 1 , if they had prior knowledge of all three services. Contrary to expectations, those respondents who knew about these services had a lower probability of responding 'yes'. This seems counterintuitive, as individuals more familiar with the services provided by an ecosystem are expected to value that ecosystem more than those who are not. However, more knowledge regarding the services provided by an ecosystem may also be an indication of more knowledge about this particular ecosystem or about ecology in general. Those individuals more familiar with the services provided by LNNP may consider that the 2,500 hectares affected by the wildfires are a small area compared to the 40,000 hectares or so of páramo under protection within the park. They may also know that fires are common in páramo ecosystems and are arguably a natural component of the disturbance regimes that maintain the integrity of the system. These more informed respondents may also be aware of the human dynamic of pastoralist fires and do not believe that a higher entrance fee would solve the problem.

\subsubsection{Open-Ended WTP Results}

Responses were analyzed using a censored Tobit model. Three different models were regressed in order to accommodate different functional forms of the WTP_YES and PRICE variables and to test for starting-point bias (Whitehead, 2002). The results are summarized in Tāble 5. 
The INTERACTION variable, which was included to account for the anchoring effect, was found to be positive and statistically significant in all models. Respondents who were showed higher bids $(A)$ in the closed ended exercise were more likely to have higher maximum WTP amounts. There are no statistically significant coefficients for the PRICE and WTP YES variables in models 2 and 3. This may imply that the anchoring effect is accounted for with the interaction of the PRICE shown to the respondent and their likelihood of responding 'yes' to the exercise.

The variable indicating if the respondent was visiting the park for the first time (FIRSTVIS) was associated with positive and statistically significant coefficients in models 1 and 2, indicating that repeat visitors experience diminishing marginal utility.

The parameter estimate associated with the VERSION variable was positive and statistically significant in all three models. This indicates that respondents who went through the CV exercise before they were asked about their awareness of the ecological services provided by the park showed a higher WTP. It was expected that respondents who were asked about their awareness of the ecological services provided by the park-and thus informed or reminded about these services - before going through the CV exercise would show a higher WTP, as they had more information about these services. The results, however, did not support this hypothesis. It is possible that respondents perceived the extra information about ecological services as a blatant attempt to increase their WTP, or they resisted paying for a public good.

Respondents who were traveling with children showed a higher WTP than those who did not, as indicated by the positive and statistically significant parameter estimate associated with the CHILD variable in models 1 and 3. This result could be an indicator of bequest values.

Younger survey respondents were found to have higher WTP values for restoration than respondents who were at least $40(O L D E R)$. Environmentalism is a recent phenomenon in the developing world, and pro-environment attitudes may be more common among the young. Older individuals may also be more skeptical that the additional fees collected would be used for restoration of LNNP.

Income - as proxied by the tax stratum of the respondent's home (Alvarez, 2008) - was positively related to maximum WTP for restoration. This supports the theory higher incomes result in larger demand for goods and services. Individuals with higher incomes have more disposable income that can be spent in recreation or ecological restoration.

The coefficient associated with the MEMBER variable indicates that individuals who are members of, or donate money to, environmental organizations have a higher WTP for ecological restoration than those who do not. This is not a surprising result, as these individuals were expressing their non-market environmental preferences through the survey.

\section{Discussion}

The results obtained in the analysis highlight several important issues concerning protected area management in the developing world. At the forefront of these issues is the role of nonmarket valuation in the improvement of park management. Nonmarket valuation methods are particularly suitable for answering questions concerning visitors' WTP for improvements in park management or park quality. Moreover, nonmarket valuation can help answer questions like 'what are parks worth to society?' Such questioning of the worth or value of parks to society is incomplete without an examination of the role and purpose of PAs in the $21^{\text {st }}$ century. In this section, the results obtained from this study are used to better understand these issues, particularly as they relate to LNNP. However, the discussion is extended to other PAs in the developing world.

The average WTP for restoration elicited through the closed-ended DC exercise was found to be 3,969 COP, or about 2 USD per person. The average WTP for restoration elicited through the open-ended exercise was found to be 6,742 COP or about 3.50 USD. If these average values are representative of the visitor population and visitation in 2007 remained at 2006 levels, park management authorities could have raised between 238 and 405 million COP, or between 119,000 and 202,000 USD for ecological restoration in 2007.

These figures indicate that ecological restoration is valuable enough to the visiting public to be financed directly by visitors through higher entrance fees or some form of suggested donation mechanism. While the annual estimates of WTP may not be high enough to finance a one-time investment to restore 2,500 hectares of páramo, these sums could be used to finance an ongoing small-scale restoration program. If park authorities were to finance park improvements or restoration, it is important that they inform visitors of the problem and proposed improvement. In the case of LNNP, the authorities should inform visitors of the magnitude of the fires, the total cost of restoration, and the proposed fee increase.

In terms of the park's worth to society, the per capita CS estimates associated with reported visits over the seven-month period analyzed range from a low of 83,754 COP or 42 USD to a high of 353,483 COP or 176 USD. For reference, the Colombian Parks Service's (UAESPNN) annual budget for 2007 was 23.5 billion COP or about 12 million USD (Alvarez, 2008). The most conservative estimate of total consumer surplus, at 2.2 billion COP, is equivalent to $9.4 \%$ of the entire Colombian parks system budget. The UAESPNN is responsible for the 
management of 55 protected areas. Since this CS estimate was based on visitation data from just 7 of 12 months $(58.3 \%)$, it might seem reasonable to extrapolate the findings to an entire year. On an annual basis, the lowest value would be 3.8 billion COP (\$1.9 million USD), or about 16\% of UAESPNN's annual budget.

These results also support the notion that PAs in the developing world are underfunded (McNeely, 1995), as the surplus value created by recreational use is likely to exceed the park's budget. Moreover, while estimates from the simple zonal travel cost should be taken as a 'ball park' estimates (Clawson and Knetsch, 1966) rather than an exact measure, they do highlight the large economic value that areas set aside for conservation and public access create. Conservation is one item in a list of policy priorities that include such important government programs as health and sanitation, basic education and poverty alleviation. The authors do not intend to argue that more funds should be allocated to parks at the expense of such policy priorities. However, PAs create large amounts of surplus value, and investments in park management, improvement and enlargement are likely to yield high social returns.

Also underscored is a larger question about the role of biodiversity conservation and parks in societies throughout the developing world. It has been suggested that contingent valuation can be used as way to gauge people's WTP for entrance fees to PAs (Shamsudin et al., 2009; Samdin et al., 2009). Intuitively, high fees can be used to prevent overcrowding and resource degradation associated with recreational uses. This highlights the notion that there is an inherent tradeoff between biodiversity and development, or that recreational and other uses of PAs are incompatible with conservation. However, there is evidence that synergies between biodiversity conservation and economic and social development exist, and that such synergies can be developed in protected area management (Child, 2004).

Protected areas in the developing world have multiple constituencies (Murphree, 2004), ranging from local people to government and international non-governmental organizations. However, the most important constituency of parks is society at large. The inscription in Yellowstone's Roosevelt Arch, "For the Benefit and Enjoyment of the People", serves as a reminder of the role and purpose of parks. While biodiversity conservation and the preservation of ecological and evolutionary processes must always be the imperative in protected area management, it is important to remember that parks exist because society at large believes in the importance of maintaining these areas into perpetuity; society values its parks. Through non-market valuation techniques such as TCM and CVM, the extent of this value can be estimated.

Since it is society as a whole who stands to benefit from the conservation and enjoyment of a PA, it is important to find ways in which all members have access to these areas. The CV results indicate that visitors are willing to pay a higher entrance fee if it ensures a better protection of the park or an improvement in park quality. However, this WTP is sensitive to important demographic variables such as income. Income is particularly important as a higher entrance fee could preclude visitation by poorer individuals. This could mean that poorer segments of the Colombian population would not have access to the enjoyment of an area that was explicitly protected for them, nor would they benefit from environmental education that is an important component of the sustainable management of PAs.

On the other hand, the chronic underfunding of PAs in the developing world could be partially addressed by increasing entrance fees. While this presumably will increase park revenue, higher entrance fees may result in lower visitation rates, as some individuals will not be willing to pay the higher fees. In turn, lower visitation rates would result in a decrease in the surplus value of the park, as measured with the TCM. A park manager with the objective of increasing the surplus value of parks to society at large should then attempt to increase visitation. Higher visitation rates, even at the existing entrance fee, will result in higher park revenues. However, managers must also weigh in considerations of overcrowding and resource degradation caused by unsustainable levels of visitation.

The case of LNNP is very particular in this respect. Even though the park is relatively large, the majority of people visit only the northwest portion of the park, which has a road access to the base of Nevado del Ruiz (Figure 1), the most notorious of several glaciated peaks. Visitors follow the road to the base of the peak, and a professional guide takes them on a mile long hike to the 5,125 meters altitude mark. This trail is likely to suffer from overcrowding and degradation due to erosion. However, only the most adventurous travelers visit the rest of the park, as permit requirements and lack of accessibility prevent higher visitation rates.

In this case, park managers could reduce pressure on the northwest portion of the park by facilitating access to the other peaks in the park. Other visitors may be interested in exploring other remote areas of the park, but cannot do so due to lack of accessibility. In that sense, increased access would result in higher park revenues, as more people are likely to visit the park. Opening other areas of the park for recreational use would also create opportunities for income generation in the local communities, as higher levels of tourism imply that demand for food, guidance, and other services would increase in those areas. Therefore, increased access to the park would not only create a surplus value for the visitors, but also create income generation opportunities for local people, making them more likely to join conservation efforts.

Parks are valuable to society not only because of the ecosystem services they provide and the ecological 
processes that they protect, but also because of the recreational opportunities that become available to the public at large. Managers of protected areas must consider the social tradeoffs associated with increased entrance fees, namely reduced accessibility to large portions of the population. In developing nations where a majority of people belong to the middle and lower income groups, this is especially relevant as people from lower income strata are no less entitled to the benefits of PAs than the wealthy or the foreign. Demographic trends towards urbanization will only increase the importance of PAs as places were an urbanized citizenry can interact and learn about nature, and possibly develop a cultural attachment to parks and the resources within them.

\section{Conclusions}

Economic valuation of protected areas in general and of parks and reserves in the developing world in particular is an area where little research exists but much more is needed. As is the case with LNNP, most parks in the developed and developing world alike are highly valuable but are extremely undervalued under the existing institutional framework, opening the way for other non-conservation land uses. Research on the total economic value of these parks and reserves can fill an important gap and allow decision-makers and the general public to make more informed choices regarding these important social assets.

In the case of LNNP, the economic value created by recreational use of the park is large relative to the budget of the system of protected areas as a whole, which suggests that LNNP contributes positively to Colombian society. Furthermore, visitors are willing to pay increased entrance fees to finance restoration of areas damaged by wildfires. However, park authorities are cautioned in regards to the use of increased entrance fees as a way to protect PAs from overcrowding and overuse, as high fees may prevent large segments of the population from the enjoyment of these natural assets, thereby decreasing their value to society. Consumer surplus measures of the economic value created by parks would, for example, decline if access to PAs was curtailed. Economic valuation of protected areas is an important component of sustainable park development, where increased access and enjoyment of parks does not diminish the provision of ecosystem services and the protection of ecological processes.

\section{References}

Alvarez, S. (2008). Valuing Forest Restoration and Recreational Benefits of a National Park in Andean Colombia. Unpublished M.S. Thesis. University of Florida, USA.

Arrow K.J. \& Lehmann, E.L. (2005). Harold Hotelling 1895-1973. Biographical Memoirs, 87. Washington, D.C.: National Academies Press.

Bockstael, N.E., McConnell, K.E., \& Strand I.E. (1991). Recreation. In J.B. Braden and C.D. Kolstad (Eds.), Measuring the Demand for Environmental Quality. Amsterdam: Elsevier Science Publishing pp. 227-270.

Bowes, M.D. \& Loomis J.B. (1980). A note on the use of travel cost models with unequal zonal populations. Land Economics, 56, 465-470.

Cameron, T.A. (1992). Combining Contingent Valuation and Travel Cost Data for the Valuation of Nonmarket Goods. Land Economics, 68, 3, 302-317.

Convention on Biological Diversity (2005). Handbook of the Convention on Biological Diversity. [Online] Available: http://www.cbd.int/convention/refrhandbook.shtml (September 3, 2010)

Child, B. (2004). Parks in Transition: Biodiversity, Development and the Bottom Line. In B. Child (Ed.), Parks in Transition: Biodiversity, Rural Development and the Bottom Line. London: Earthscan pp. 233-256.

Clawson, M. \& Knetsch J.L. (1966). Economics of Outdoor Recreation. Baltimore: John Hopkins University Press.

Fleming, C.M. \& Cook, A. (2007). The recreational value of Lake McKenzie: an application of the travel cost method. Paper presented at the 51st Annual Conference of the Australian Agricultural and Resource Economics Society, Queenstown, New Zealand.

Hanemann, W.M. (1994). Valuing the Environment Through Contingent Valuation. Journal of Economic Perspectives, 8, 4, 19-43.

Hanemann, W.M. (1984). Welfare Evaluations in Contingent Valuation Experiments with Discrete Responses. American Journal of Agricultural Economics, 66, 3, 332-341.

Horton, B., Colarullo, G., Bateman, I.J., \& Peres, C.A. (2003). Evaluating non-user willingness to pay for a large scale conservation programme in Amazonia: a UK/Italian contingent valuation study. Environmental Conservation, 30, 2, 139-146.

Jabarin, A.S. \& Damhoureyeh, S.A. (2006). Estimating the recreational benefits of Dibeen national park in Jordan using contingent valuation and travel cost methods. Pakistan Journal of Biological Sciences, 9, 12, 2198-2206.

Loomis J., Tadjion, O., Watson, P., Wilson, J., Davies, S., \& Thilmany D. (2009). A Hybrid Individual-Zonal Travel Cost Model for Estimating the Consumer Surplus of Golfing in Colorado. Journal of Sports Economics, 


\section{$10,2,155-167$.}

Loomis, J., Kent, P., Strange, L., Fausch, K., \& Covich A. (2000). Measuring the total economic value of restoring ecosystem services in an impaired river basin: results from a contingent valuation survey. Ecological Economics, 33, 103-117.

MacMillan, D.C. \& Duff E.I. (1998). Estimating the non-market costs and benefits of native woodland restoration using the contingent valuation method. Forestry, 71, 247-259.

Maddala G.S. \& Flores-Lagunes, A. (2001). Qualitative Response Models. In B.H. Baltagi (Ed.), A Companion to Theoretical Econometrics. Oxford: Blackwell pp. 366-382.

Maharana, I., Rai, S.C., \& Sharma, E. (2000). Valuing ecotourism in a sacred lake of the Sikkim Himalaya, India. Environmental Conservation, 27, 3, 269-277.

Mathieu, L.F., Langford, I.H., \& Kenyon, W. (2003). Valuing marine parks in a developing country: a case study of the Seychelles. Environment and Development Economics, 8, 373-390.

McNeely, J.A. (1995). Partnerships for Conservation: An Introduction. In J.A. McNeely (Ed.), Expanding Partnerships in Conservation. Washington, D.C.: Island Press pp. 1-10.

Moffit, R.A. (1999). New Developments in Econometric Methods for Labor Market Analysis. In O. Ashenfelter and D. Card (Eds.), Handbook of Labor Economics, Vol. 3. Amsterdam: Elsevier pp. 1367-1397.

Murphree, M.W. (2004). Who and What are Parks for in Transitional Societies? In B. Child (Ed.), Parks in Transition: Biodiversity, Rural Development and the Bottom Line. London: Earthscan pp. 217-231.

Navrud, S., \& Mungatana, E.D. (1994). Environmental valuation in developing countries: the recreational value of wildlife viewing. Ecological Economics, 11, 135-151.

Ojeda, M.I., Mayer, A.S., \& Solomon, B.D. (2008). Economic valuation of environmental services sustained by water flows in the Yaqui river delta. Ecological Economics, 65, 155-166.

Samdin, Z., Aziz, Y.A., Radam, A., \& Yacob, M.R. (2010). Factors Influencing the Willingness to Pay for Entrance Permit: The Evidence from Taman Negara National Park. Journal of Sustainable Development, 3, 3, 212-220.

Shah, A. (1995). The Economics of Third World National Parks: Issues of Tourism and Environmental Management. Aldershot, UK: Edward Elgar.

Shamsudin, N.R., Shamsudin, M.N., Radam, A., \& Shuib, A. (2009). Willingness to Pay towards the Conservation of Ecotourism Resources at Gunung Gede Pangrango National Park, West Java, Indonesia. Journal of Sustainable Development, 2, 2, 173-186.

VanKooten G.C. \& Bulte, E. (2000). The Economics of Nature: Managing Biological Assets. Malden, MA: Blackwell.

Weldesilassie, A.B., Fror, O., Boelee, E., \& Dabbert, S. (2009). The Economic Value of Improved Wastewater Irrigation: A Contingent Valuation Study in Addis Ababa, Ethiopia. Journal of Agricultural and Resource Economics, 34, 3, 428-449.

Whitehead, J.C. (2002). Incentive Incompatibility and Starting-Point Bias in Iterative Valuation Questions. Land Economics, 78, 2, 285-297.

Willis, K.G., \& Garrod, G.D. (1991). An Individual Travel Cost Method of Evaluating Forest Recreation. Journal of Agricultural Economics, 42,1,33-42.

Yacob, M.R., Radam, A., \& Shuib, A. (2009). A Contingent Valuation Study of Marine Parks Ecotourism: The Case of Pulau Payar and Pulau Redang in Malaysia. Journal of Sustainable Development, 2, 2, 95-104.

Table 1. Travel cost model results

\begin{tabular}{|c|c|c|c|}
\hline & Intercept & Slope & \\
\hline Functional Form & $\begin{array}{l}\text { Est of } \beta_{0} \\
\text { (p-value) }\end{array}$ & $\begin{array}{l}\text { Est. of } \beta_{1} \\
\text { (p-value) }\end{array}$ & $R^{2}$ \\
\hline 1) $V_{i}=\beta_{0}+\beta_{1} T C_{i}$ & $\begin{array}{c}1646.571 \text { *** } \\
(0.0043)\end{array}$ & $\begin{array}{l}-0.005 * \\
(0.0779)\end{array}$ & 0.256 \\
\hline 2) $V_{j}=\beta_{o}+\beta_{1} \operatorname{Ln}\left(T C_{j}\right)$ & $\begin{array}{c}8671.510 * * \\
(0.0417)\end{array}$ & $\begin{array}{c}-666.996^{*} \\
(0.0637)\end{array}$ & 0.279 \\
\hline 3) $\operatorname{Ln}\left(V_{j}\right)=\beta_{0}+\beta_{1} T C_{j}$ & $\begin{array}{l}7.269 * * * \\
(<0.0001)\end{array}$ & $\begin{array}{c}-7.18 \times 10^{-5 * * *} \\
(0.0133)\end{array}$ & 0.441 \\
\hline 4) $\operatorname{Ln}\left(V_{i}\right)=\beta_{0}+\beta_{1} \operatorname{Ln}\left(T C_{i}\right)$ & $\begin{array}{c}15.989 * * * \\
-0.0025\end{array}$ & $\begin{array}{c}-0.844 * * \\
-0.0361\end{array}$ & 0.341 \\
\hline
\end{tabular}

Note: Triple, double and single asterisks indicate statistical significance at the

$0.01,0.05$, and 0.10 level, respectively. 
Table 2. Consumer surplus estimates by state, in thousands COP and USD

\begin{tabular}{|c|c|c|c|c|}
\hline State & Model 1 & Model 2 & Model 3 & Model 4 \\
\hline \multicolumn{5}{|l|}{ Colombian Pesos: } \\
\hline Antioquia & $\$ 687,045$ & $\$ 632,052$ & $\$ 481,219$ & $\$ 1,738,630$ \\
\hline Atlántico & $\$ 171,332$ & $\$ 169,611$ & $\$ 134,707$ & $\$ 625,650$ \\
\hline Boyacá & $\$ 10,060$ & $\$ 26,423$ & $\$ 32,039$ & $\$ 320,053$ \\
\hline Caldas & $\$ 216,696$ & $\$ 200,466$ & $\$ 146,783$ & $\$ 351,178$ \\
\hline Cesar & $\$ 150,378$ & $\$ 135,585$ & $\$ 101,225$ & $\$ 295,225$ \\
\hline Cundinamarca & $\$ 402,645$ & $\$ 469,938$ & $\$ 407,589$ & $\$ 2,501,745$ \\
\hline Huila & $\$ 147,386$ & $\$ 133,400$ & $\$ 100,316$ & $\$ 320,498$ \\
\hline Nariño & $\$ 0$ & $\$ 207$ & $\$ 14,092$ & $\$ 352,915$ \\
\hline Quindío & $\$ 111,130$ & $\$ 101,554$ & $\$ 74,844$ & $\$ 187,532$ \\
\hline Risaralda & $\$ 180,310$ & $\$ 164,093$ & $\$ 121,227$ & $\$ 310,729$ \\
\hline Santander & $\$ 65,054$ & $\$ 84,164$ & $\$ 76,885$ & $\$ 527,349$ \\
\hline Tolima & $\$ 344,530$ & $\$ 330,020$ & $\$ 237,122$ & $\$ 535,160$ \\
\hline Valle del Cauca & $\$ 351,220$ & $\$ 342,846$ & $\$ 270,182$ & $\$ 1,210,861$ \\
\hline Total $(C O P)$ & $\$ 2,837,787$ & $\$ 2,790,356$ & $\$ 2,198,230$ & $\$ 9,277,525$ \\
\hline \multicolumn{5}{|l|}{ U.S. Dollars: } \\
\hline Antioquia & $\$ 344$ & $\$ 316$ & $\$ 241$ & $\$ 869$ \\
\hline Atlántico & $\$ 86$ & $\$ 85$ & $\$ 67$ & $\$ 313$ \\
\hline Boyacá & $\$ 5$ & $\$ 13$ & $\$ 16$ & $\$ 160$ \\
\hline Caldas & $\$ 108$ & $\$ 100$ & $\$ 73$ & $\$ 176$ \\
\hline Cesar & $\$ 75$ & $\$ 68$ & $\$ 51$ & $\$ 148$ \\
\hline Cundinamarca & $\$ 201$ & $\$ 235$ & $\$ 204$ & $\$ 1,251$ \\
\hline Huila & $\$ 74$ & $\$ 67$ & $\$ 50$ & $\$ 160$ \\
\hline Nariño & $\$ 0$ & $\$ 0.10$ & $\$ 7$ & $\$ 176$ \\
\hline Quindío & $\$ 56$ & $\$ 51$ & $\$ 37$ & $\$ 94$ \\
\hline Risaralda & $\$ 90$ & $\$ 82$ & $\$ 61$ & $\$ 155$ \\
\hline Santander & $\$ 33$ & $\$ 42$ & $\$ 38$ & $\$ 264$ \\
\hline Tolima & $\$ 172$ & $\$ 165$ & $\$ 119$ & $\$ 268$ \\
\hline Valle del Cauca & $\$ 176$ & $\$ 171$ & $\$ 135$ & $\$ 605$ \\
\hline Total (US) & $\$ 1,419$ & $\$ 1,395$ & $\$ 1,099$ & $\$ 4,639$ \\
\hline
\end{tabular}

Note: The estimation reflects values for 2007 and was conducted using COP, then values were converted to USD assuming $1 \mathrm{USD}=2,000 \mathrm{COP}$. The exchange rate ranged from $1,950-2,080$ COP for 1 USD during the time of the study but 2,000 was used to simplify the conversions. 
Table 3. Summary statistics of variables in the contingent valuation analysis $(N=64)$

\begin{tabular}{|c|c|c|c|c|}
\hline Variable & Description & $\begin{array}{c}\text { Mean } \\
\text { (St. Dev.) }\end{array}$ & Min. & Max \\
\hline WTP_YES & $\begin{array}{c}1 \text { if WTP specified fee, } \\
0 \text { otherwise }\end{array}$ & $\begin{array}{c}0.813 \\
(0.393)\end{array}$ & 0 & 1 \\
\hline$M A X \_W T P$ & $\begin{array}{l}\operatorname{maximum} \text { WTP } \\
\text { in } \operatorname{COP}(1,000)\end{array}$ & $\begin{array}{c}6.742 \\
(5.080)\end{array}$ & 0 & 30.0 \\
\hline $\operatorname{Ln}\left(M A X \_W T P\right)$ & $\begin{array}{l}\text { natural logarithm } \\
\text { of } M A X \_W T P\end{array}$ & $\begin{array}{l}7.783 \\
(2.822)\end{array}$ & 0 & 10.3 \\
\hline PRICE & $\begin{array}{l}\text { specified fee increase } \\
\text { in COP }(1,000)\end{array}$ & $\begin{array}{c}0.503 \\
(0.225)\end{array}$ & 2.0 & 8.0 \\
\hline $\operatorname{Ln}(P R I C E)$ & $\begin{array}{l}\text { natural logarithm } \\
\text { of PRICE }\end{array}$ & $\begin{array}{c}8.402 \\
(0.523)\end{array}$ & 7.6 & 9.0 \\
\hline INTERACTION & $\begin{array}{c}\text { Product of } \\
W T P \_Y E S \times P R I C E\end{array}$ & $\begin{array}{l}3.968 \\
(2.794)\end{array}$ & 0 & 8 \\
\hline FIRSTVIS & $\begin{array}{c}1 \text { if first visit to park, } \\
0 \text { otherwise }\end{array}$ & $\begin{array}{c}0.703 \\
(0.460)\end{array}$ & 0 & 1 \\
\hline RVISIT & $\begin{array}{c}1 \text { if visits parks regularly, } \\
0 \text { otherwise }\end{array}$ & $\begin{array}{c}0.594 \\
(0.495)\end{array}$ & 0 & 1 \\
\hline PRIMPURP & $\begin{array}{l}1 \text { if visit is primary purpose } \\
\text { of trip, } 0 \text { otherwise }\end{array}$ & $\begin{array}{c}0.813 \\
(0.393)\end{array}$ & 0 & 1 \\
\hline TOURBUS & $\begin{array}{c}1 \text { if used a tour bus, } \\
0 \text { otherwise }\end{array}$ & $\begin{array}{c}0.281 \\
(0.453)\end{array}$ & 0 & 1 \\
\hline FIREAWARE & $\begin{array}{c}1 \text { if aware of fires, } \\
0 \text { otherwise }\end{array}$ & $\begin{array}{c}0.234 \\
(0.427)\end{array}$ & 0 & 1 \\
\hline ECOAWARE & $\begin{array}{l}1 \text { if aware of ecological } \\
\text { services, } 0 \text { otherwise }\end{array}$ & $\begin{array}{c}0.531 \\
(0.503)\end{array}$ & 0 & 1 \\
\hline VERSION & $\begin{array}{l}1 \text { if } \mathrm{CV} \text { before awareness } \\
\text { questions, } 0 \text { otherwise }\end{array}$ & $\begin{array}{c}0.516 \\
(0.504)\end{array}$ & 0 & 1 \\
\hline CHILD & $\begin{array}{c}1 \text { if minor present in group, } \\
0 \text { otherwise }\end{array}$ & $\begin{array}{c}0.469 \\
(0.503)\end{array}$ & 0 & 1 \\
\hline$O L D E R$ & $\begin{array}{c}1 \text { if older than } 40 \\
0 \text { otherwise }\end{array}$ & $\begin{array}{c}0.375 \\
(0.488)\end{array}$ & 0 & 1 \\
\hline INCOME & $\begin{array}{c}\text { residential strata } \\
(1-6)\end{array}$ & $\begin{array}{l}3.578 \\
(1.166)\end{array}$ & 1 & 6 \\
\hline$M E M B E R$ & $\begin{array}{l}1 \text { if member to environmental } \\
\text { organization, } 0 \text { otherwise }\end{array}$ & $\begin{array}{c}0.141 \\
(0.350)\end{array}$ & 0 & 1 \\
\hline GENDER & $\begin{array}{c}1 \text { if male, } \\
0 \text { otherwise }\end{array}$ & $\begin{array}{c}0.625 \\
(0.488)\end{array}$ & 0 & 1 \\
\hline
\end{tabular}


Table 4. Probit results of the dichotomous choice CV experiment

\begin{tabular}{|c|c|c|c|c|c|}
\hline \multirow[b]{2}{*}{ Variable } & \multicolumn{2}{|c|}{ Parameter } & \multicolumn{2}{|c|}{ Marginal Effect } & \multirow[b]{2}{*}{$x$} \\
\hline & Estimate & p-value & $(d y / d x)$ & p-value & \\
\hline \multicolumn{6}{|l|}{ Model 1; } \\
\hline INTERCEPT & 0.290 & 0.810 & & & \\
\hline PRICE & $-2.397 * *$ & 0.048 & $-0.036 * *$ & 0.030 & 5.031 \\
\hline FIRSTVIS & 0.581 & 0.321 & 0.1039 & 0.403 & 0.703 \\
\hline RVISIT & $1.225^{* *}$ & 0.021 & $0.222 * *$ & 0.019 & 0.594 \\
\hline PRIMPURP & $0.999 *$ & 0.062 & 0.223 & 0.122 & 0.813 \\
\hline TOURBUS & $0.804 *$ & 0.082 & 0.097 & 0.098 & 0.281 \\
\hline FIREAWARE & 0.693 & 0.259 & 0.081 & 0.153 & 0.234 \\
\hline ECOAWARE & $-1.211 * *$ & 0.028 & $-0.183 * *$ & 0.029 & 0.531 \\
\hline VERSION & 0.469 & 0.225 & 0.0719 & 0.283 & 0.516 \\
\hline CHILD & -0.373 & 0.413 & -0.0579 & 0.413 & 0.469 \\
\hline OLDER & 0.752 & 0.281 & 0.101 & 0.167 & 0.375 \\
\hline INCOME & 0.218 & 0.213 & 0.033 & 0.295 & 3.578 \\
\hline$M E M B E R$ & 0.711 & 0.331 & 0.075 & 0.179 & 0.141 \\
\hline GENDER & -0.972 & 0.104 & $-0.128 *$ & 0.083 & 0.625 \\
\hline \multicolumn{6}{|l|}{ Model 2; } \\
\hline INTERCEPT & $7.497 *$ & 0.081 & & & \\
\hline $\operatorname{Ln}(P R I C E)$ & $-0.994 *$ & 0.057 & $-0.152 * *$ & 0.042 & 8.402 \\
\hline FIRSTVIS & 0.560 & 0.329 & 0.100 & 0.408 & 0.703 \\
\hline RVISIT & $1.213 * *$ & 0.016 & $0.223 * *$ & 0.021 & 0.594 \\
\hline PRIMPURP & $0.973^{*}$ & 0.068 & 0.218 & 0.132 & 0.813 \\
\hline TOURBUS & $0.825^{*}$ & 0.086 & $0.100 *$ & 0.086 & 0.281 \\
\hline FIREAWARE & 0.687 & 0.261 & 0.083 & 0.160 & 0.234 \\
\hline ECOAWARE & $-1.165 * *$ & 0.032 & $-0.1785 * *$ & 0.031 & 0.531 \\
\hline VERSION & 0.4807 & 0.210 & 0.075 & 0.265 & 0.516 \\
\hline CHILD & -0.305 & 0.501 & -0.047 & 0.499 & 0.469 \\
\hline$O L D E R$ & 0.687 & 0.302 & 0.095 & 0.208 & 0.375 \\
\hline INCOME & 0.208 & 0.246 & 0.032 & 0.312 & 3.578 \\
\hline$M E M B E R$ & 0.628 & 0.388 & 0.070 & 0.240 & 0.141 \\
\hline GENDER & $-1.008^{*}$ & 0.083 & $-0.135^{*}$ & 0.074 & 0.625 \\
\hline
\end{tabular}

Note: Double and single asterisks indicate significance at the 0.05 and 0.10 level respectively. 
Table 5. Tobit results of the open-ended willingness to pay models

\begin{tabular}{|c|c|c|c|}
\hline Variable & $\begin{array}{c}\text { Model } 1 \\
\text { Parameter Est. } \\
\text { (p-value) }\end{array}$ & $\begin{array}{c}\text { Model } 2 \\
\text { Parameter Est. } \\
\text { (p-value) }\end{array}$ & $\begin{array}{c}\text { Model } 3 \\
\text { Parameter Est. } \\
\text { (p-value) }\end{array}$ \\
\hline INTERCEPT & $\begin{array}{c}-4.9261 * \\
(0.091)\end{array}$ & $\begin{array}{l}-3.5560 \\
(0.235)\end{array}$ & $\begin{array}{c}-5.3602 * \\
(0.066)\end{array}$ \\
\hline WTP_YES & $\begin{array}{l}\text { N/A } \\
\text { N/A }\end{array}$ & $\begin{array}{l}\text { N/A } \\
\text { N/A }\end{array}$ & $\begin{array}{l}2.5150 \\
(0.181)\end{array}$ \\
\hline PRICE & $\begin{array}{l}\text { N/A } \\
\text { N/A }\end{array}$ & $\begin{array}{c}-0.4224 \\
(0.131)\end{array}$ & $\begin{array}{l}\text { N/A } \\
\text { N/A }\end{array}$ \\
\hline INTERACTION & $\begin{array}{l}0.9464 * * * \\
(<0.0001)\end{array}$ & $\begin{array}{l}1.1449 \text { *** } \\
(<0.0001)\end{array}$ & $\begin{array}{c}0.7185 * * * \\
(0.006)\end{array}$ \\
\hline FIRSTVIS & $\begin{array}{l}2.1393 * \\
(0.082)\end{array}$ & $\begin{array}{c}2.0813^{*} \\
(0.086)\end{array}$ & $\begin{array}{l}1.9372 \\
(0.114)\end{array}$ \\
\hline RVISIT & $\begin{array}{l}-0.7229 \\
(0.513)\end{array}$ & $\begin{array}{l}-1.0967 \\
(0.328)\end{array}$ & $\begin{array}{l}-1.0258 \\
(0.361)\end{array}$ \\
\hline PRIMPURP & $\begin{array}{l}0.2520 \\
(0.855)\end{array}$ & $\begin{array}{l}-0.0217 \\
(0.987)\end{array}$ & $\begin{array}{l}-0.1803 \\
(0.898)\end{array}$ \\
\hline TOURBUS & $\begin{array}{l}0.2928 \\
(0.803)\end{array}$ & $\begin{array}{l}0.2945 \\
(0.800)\end{array}$ & $\begin{array}{l}0.2364 \\
(0.839)\end{array}$ \\
\hline FIREAWARE & $\begin{array}{l}-0.0225 \\
(0.985)\end{array}$ & $\begin{array}{l}-0.0588 \\
(0.961)\end{array}$ & $\begin{array}{l}-0.1199 \\
(0.922)\end{array}$ \\
\hline ECOAWARE & $\begin{array}{l}0.1723 \\
(0.889)\end{array}$ & $\begin{array}{l}0.4594 \\
(0.709)\end{array}$ & $\begin{array}{l}0.4023 \\
(0.745)\end{array}$ \\
\hline VERSION & $\begin{array}{c}2.6836 * * \\
(0.014)\end{array}$ & $\begin{array}{c}2.6738 * * \\
(0.013)\end{array}$ & $\begin{array}{c}2.3998 * * \\
(0.029)\end{array}$ \\
\hline CHILD & $\begin{array}{l}2.0545^{*} \\
(0.060)\end{array}$ & $\begin{array}{l}1.7512 \\
(0.109)\end{array}$ & $\begin{array}{l}1.9478 \% \\
(0.073)\end{array}$ \\
\hline$O L D E R$ & $\begin{array}{c}-2.8651 * * \\
(0.021)\end{array}$ & $\begin{array}{c}-2.8289 * * \\
(0.021)\end{array}$ & $\begin{array}{l}-2.8131 \\
(0.022)\end{array}$ \\
\hline$I N C O M E$ & $\begin{array}{c}1.3711 \text { \%** } \\
(0.005)\end{array}$ & $\begin{array}{c}1.4603 * * * \\
(0.003)\end{array}$ & $\begin{array}{l}1.3546 * * * \\
(0.006)\end{array}$ \\
\hline$M E M B E R$ & $\begin{array}{c}4.1018 * * \\
(0.011)\end{array}$ & $\begin{array}{c}3.8333 * * \\
(0.016)\end{array}$ & $\begin{array}{c}3.7892 * * \\
(0.018)\end{array}$ \\
\hline GENDER & $\begin{array}{l}-0.4658 \\
(0.672)\end{array}$ & $\begin{array}{l}-0.2095 \\
(0.849)\end{array}$ & $\begin{array}{l}-0.2022 \\
(0.855)\end{array}$ \\
\hline $\begin{array}{l}\text { Model Statistics: } \\
R^{2} \\
\text { Adj. } R^{2}\end{array}$ & $\begin{array}{l}0.54 \\
0.42\end{array}$ & $\begin{array}{l}0.56 \\
0.43\end{array}$ & $\begin{array}{l}0.55 \\
0.43\end{array}$ \\
\hline
\end{tabular}

Note: Triple, double and single asterisks indicate statistical significance at the $0.01,0.05$ and 0.10 level, respectively. 


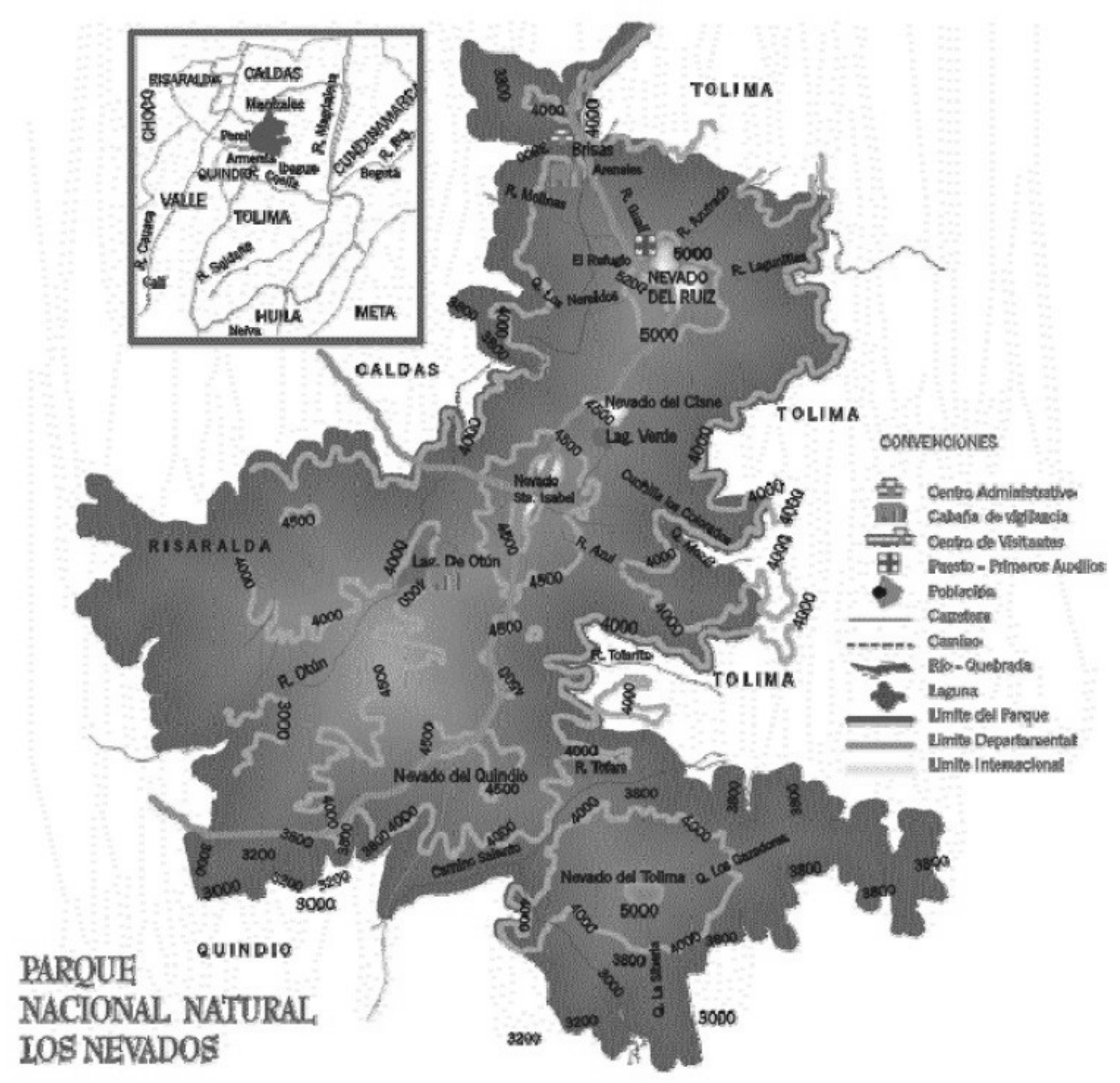

Figure 1. Map of Los Nevados National Park

Source: UAESPNN, undated. Available at http://www.parquesnacionales.gov.co 